\title{
Evaluasi Pemanfaatan Aset Barang Milik Daerah dengan Analisis Cost and Benefit (CBA) pada Stadion Mandala Krida Yogyakarta
}

\section{Utilization Evaluation of Regional Property Assets Using the Cost and Benefit Analysis (CBA) at Mandala Krida Stadium Yogyakarta}

\author{
Sri Wahyuni ${ }^{1, a)}$, Rifki Khoirudin ${ }^{2, b)}$ Novi Irawati $^{1, c)}$ \& Ariyanto Adhi Nugroho ${ }^{3, d)}$ \\ ${ }^{1)}$ Sekolah Tinggi Pariwisata Ambarrukmo (STIPRAM), Yogyakarta. \\ ${ }^{2)}$ Ekonomi Pembangunan, FEB, Universitas Ahmad Dahlan, Yogyakarta. \\ ${ }^{3)}$ Fakultas Ekonomi dan Bisnis, Universitas Sebelas Maret, Surakarta.
} Koresponden : ${ }^{a)}$ yiyieid@yahoo.com, $\left.{ }^{b}\right)$ rifki_khoirudin@yahoo.com, ${ }^{c}$ irawati_novie@yahoo.co.id \&

\begin{abstract}
ABSTRAK
Pada penelitian ini, akan dilihat hasil dari Evaluasi Pemanfaatan Aset Barang Milik Daerah Pada Stadion Mandala Krida Yogyakarta. Evaluasi pemanfaatan aset pada Stadion Mandala Krida Yogyakarta ini dilakukan dengan menggunakan analisis CBA (Cost and Benefit Analysis) dan SWOT (Strenghts, Weakness, Opportunity and Threats). Penelitian ini menggunakan data survey lapangan pada bulan Desember 2018. Perbandingan antara pendapatan dan biaya adalah lebih besar biaya sehingga menimbulkan net income yang negatif, sehingga Net Present Value (NPV) juga akan negatif. Pemanfaatan yang ideal dari hasil analisis SWOT adalah sebagai sarana olahraga. Hasil dari evaluasi pemanfaatan aset pada Stadion Mandala Krida Yogyakarta mengindikasikan bahwa untuk pengelolaan dari pemanfaatan aset tersebut, sebaiknya dilakukan melalui Badan Layanan Umum.
\end{abstract}

Kata Kunci : manajemen fasilitas, cost and benefit analysis, pemanfaatan aset, evaluasi aset stadion, Barang Milik Daerah.

\section{PENDAHULUAN}

Aset adalah sumber daya ekonomi yang dikuasai dan/atau dimiliki oleh pemerintah sebagai akibat dari peristiwa masa lalu dan dari mana manfaat ekonomi dan/atau sosial dimasa depan diharapkan dapat diperoleh, baik oleh pemerintah maupun masyarakat serta dapat diukur dalam satuan yang, termasuk sumber daya non keuangan yang diperlukan untuk penyediaan jasa bagi masyarakat umum dan sumber-sumber daya yang diperlihara karena alasan sejarah dan budaya.

Infrastruktur dan Fasilitas sebagai Barang Milik Daerah adalah asset yang harus dikelola dengan baik, agar selalu bisa berfungsi dengan baik secara ekonomis, fektif dan efisien. Untuk itu, Infrastruktur dan Fasilitas Milik Daerah haruis selalu dievaluasi unutk menyempurnakan Sistem Pengelolaanya (Suprayitno \& Soemitro, 2018).

Barang Milik Daerah (BMD) merupakan unsur penting dalam penyelenggaraan pemerintahan khususnya dalam memberikan pelayanan kepada masyarakat. Pemerintah Daerah harus melakukan pengelolaan atas BMD agar dapat berguna bagi pemerintah dan masyarakat. Pengelolaan BMD adalah suatu proses dalam mengelola kekayaan yang telah ada sebelumnya atau yang diperoleh dari beban APBD atau perolehan lainnya yang sah yang dapat dimanfaatkan dalam kegiatan pemerintah maupun masyarakat 
Pengelolaan barang milik daerah masih menjadi permasalahan di berbagai daerah. Ketidakpedulian terhadap pengelolaan dan pemeliharaan barang milik daerah yang tidak teratur, tertib dalam melaksanakan ketentuan pengelolaan barang milik daerah dapat terlihat dari catatan atas opini Badan Pemeriksa Keuangan (BPK) terhadap keuangan pemerintah daerah yang hampir setiap tahun masih didominasi masalah penyajian aset tetap.

Begitu pentingnya peran BMD dalam mendukung jalannya tatakelola pemerintah daerah, membuat pengelolaan BMD menjadi pada salah satu indikator keberhasilan Rencana Pembangunan Jangka Menengah Daerah (RPJMD) DIY tahun 2017-2022 dengan indikator: optimalisasi aset-aset pemerintah daerah dengan peningkatan efektifitas pengelolaan asset daerah melalui pemanfaatan dan kerjasama pihak ketiga. Atas hal tersebut, maka perlu dilakukan langkah-langkah strategis dalam pelaksanaan pengelolaan Barang Milik Daerah.

Sebagai langkah strategis dalam upaya optimalisasi dan peningkatan efektifitas pengelolaan BMD tersebut, diperlukan adanya kajian yang komprehensif terhadap BMD yang telah dilakukan pemanfaatan maupun BMD idle milik Pemerintah Daerah Daerah Istimewa Yogyakarta (Pemda DIY) khususnya pada BMD strategis.

Bedasarkan pertimbangan hal tersebut diatas, dipandang perlu melakukan penelitian tentang Evaluasi Pemanfaatan Aset Barang Milik Daerah Stadion Mandala Krida Yogyakarta dengan Cost and Benefit Analysis.

\section{STUDI PUSTAKA}

Menurut David (2011), "Strategic management can be defined as the art and science of formulating, implementing, and evaluating cross-functional decisions that enable an organization to achieve its objectives". David (2011) menjelaskan bahwa proses manajemen strategis terdiri dari tiga tahapan, yaitu: memformulasikan strategi, mengimplementasikan strategi dan mengevaluasi strategi.

\section{Analisis Cost and Benefit}

Analisis biaya manfaat adalah suatu alat analisis dengan prosedur yang sistematis untuk membandingkan serangkaian biaya dan manfaat yang relevan dengan sebuah aktivitas atau proyek. Tujuan akhir yang ingin dicapai adalah secara akurat membandingkan kedua nilai, manakah yang lebih besar. Selanjutnya dari hasil pembandingan ini, pengambil keputusan dapat mempertimbangkan untuk melanjutkan suatu rencana atau tidak dari sebuah aktivitas, produk atau proyek, atau dalam konteks evaluasi atas sesuatu yang telah berjalan, adalah menentukan keberlanjutannya. Adapun ciri khusus dari analisis biaya manfaat yaitu sebagai berikut:

1. Analisis biaya manfaat berusaha mengukur semua biaya dan manfaat untuk masyarakat yang kemungkinan dihasilkan dari program publik, termasuk berbagai hal yang tidak terlihat yang tidak mudah untuk diukur biaya danmanfaatnya dalam bentuk uang.

2. Analisis biaya manfaat secara tradisional melambangkan rasionalitas ekonomi, karena kriteria sebagian besar ditentukan dengan penggunaan efisiensi ekonomi secara global. Suatu kebijakan atau program dikatakan efisien jika manfaat bersih (total manfaat dikurangi total total biaya) adalah lebih besar dari nol dan lebih tinggi dari manfaat bersih yang mungkin dapat dihasilkan dari sejumlah alternatif investasi lainnya di sektor swasta dan publik.

3. Analisis biaya manfaat secara tradisional menggunakan pasar swasta sebagai titik tolak di dalam memberikan rekomendasi program publik.

4. Analisis biaya manfaat kontemporer, sering disebut analisis biaya manfaat sosial, dapat juga digunakan untuk mengukur pendistribusian kembali manfaat.

Analisis Biaya Manfaat mengandung beberapa kekuatan. Kekuatan Analisis Biaya Manfaat tersebut adalah sebagai berikut. 
1. Biaya dan manfaat diukur dengan nilai uang, sehingga memungkinkan analis untuk mengurangi biaya dari manfaat.

2. Analisis biaya manfaat memungkinkan analis melihat lebih luas dari kebijakan atau program tertentu, dan mengaitkan manfaat terhadap pendapatan masyarakat secara keseluruhan.

3. Analisis biaya manfaat memungkinkan analis membandingkan program secara luas dalam lapangan yang berbeda.

Sebaliknya, Analisis Biaya Manfaat juga mengandung beberapa keterbatasan. Keterbatasan Analisis Biaya Manfaat adalah sebagi berikut.

1. Tekanan yang terlalu eksklusif pada efisiensi ekonomi, sehingga kriteria keadilan tidak dapat diterapkan

2. Nilai uang tidak cukup untuk mengukur daya tanggap (responsiveness) karena adanya variasi pendapatan antar masyarakat.

3. Ketika harga pasar tidak tersedia, analis harus membuat harya bayangan (shadow price) yang subyektif sifatnya.

Menurut Lawrence \& Mears (2004), tahapan dasar dalam melakukan analisis biaya manfaat secara umum meliputi:

1. Penetapan tujuan analisis dengan tepat.

Sebelum data dikumpulkan, penentuan tujuan analisis menjadi vital. Misalnya apakah yang akan dievaluasi nantinya hanya satu proyek/aktivitas atau beberapa.

2. Penetapan perspektif yang dipergunakan (identifikasi pemangku kepentingan yang terlibat).

Penetapan perspektif dalam memperhitungkan biaya dan manfaat perlu dilakukan dari awal untuk mempertimbangkan sensitivitas hasilnya.

3. Mengidentifikasi biaya dan manfaat

Tahapan selanjutnya yang penting adalah mengidentifikasi semua manfaat dan biaya. Secara umum dalam memperhitungkan manfaat terdapat dua komponen yaitu (i) manfaat langsung dan (ii) manfaat tidak langsung

4. Menghitung, mengestimasi, menskalakan dan mengkuantifikasi biaya dan manfaat

Setelah komponen biaya dan manfaat diidentifikasi pada tahap sebelumnya mengkuantifikasikan dalam satuan moneter (jika memungkinkan) atau menskalakan beberapa item yang tidak memiliki satuan kuantitiatif dan selanjutnya dihitung untuk seluruh nilai yang satuannya sama menjadi total biaya dan manfaat.

5. Memperhitungkan jangka waktu (discount factor)

Discount factor adalah nilai pengurang dalam masa sekarang dari manfaat dan biaya yang akan terjadi pada periode masa yang akan datang. Penggunaan discount factor sangat penting jika benefit dan biaya yang muncul lebih dari satu periode dan untuk memperhitungkan ketidakpastian.

6. Menguraikan keterbatasan dan asumsi

Karena pada tahap kedua perspektif menjadi penentu lingkup manfaat dan biaya yang diperhitungkan, maka keterbatasan atas tidak dimasukkanya hal- hal yang jauh kaitannya adalah bagian dari keterbatasan dan asumsi yang harus dijelaskan agar pengguna informasi analisis CBA memahami batasan perhitungannya.

Biaya (Cost)

Menurut Kadariah (1999), biaya dalam proyek digolongkan menjadi empat macam, yaitu Biaya Persiapan, Biaya Investasi, Biaya Operasional, dan Biaya Pemeliharaan dan Perbaikan.

1. Biaya Persiapan

Biaya persiapan adalah biaya yang dikeluarkan sebelum proyek yang bersangkutan benarbenar dilaksanakan. 
2. Biaya Investasi atau Modal

Biaya investasi biasanya didapat dari pinjaman suatu badan atau lembaga keuangan baik dari dalam negeri atau luar negeri.

3. Biaya Operasional

Biaya operasional masih dapat dibagi lagi menjadi biaya gaji untuk karyawan, biaya listrik, air dan telekomunikasi, biaya habis pakai, biaya kebersihan, dan sebagainya.

4. Biaya Pembaharuan atau Penggantian

Pada awal umur proyek biaya ini belum muncul tetapi setelah memasuki usia tertentu, biasanya pada bangunan mulai terjadi kerusakan- kerusakan yang memerlukan perbaikan.

\section{Manfaat (Benefit)}

Manfaat yang akan terjadi pada suatu proyek dapat dibagi menjadi tiga yaitu manfaat langsung, manfaat tidak langsung dan manfaat terkait, Kadariah (1999).

1. Manfaat Langsung

Manfaat langsung dapat berupa peningkatan output secara kualitatif dan kuantitatif akibat penggunaan alat-alat produksi yang lebih canggih, keterampilan yang lebih baik dan sebagainya.

2. Manfaat Tidak Langsung

Manfaat tidak langsung adalah manfaat yang muncul di luar proyek, namun sebagai dampak adanya proyek. Manfaat ini dapat berupa meningkatnya pendapatan masyarakat disekitar lokasi proyek. (sulit diukur)

3. Manfaat Terkait

Manfaat terkait yaitu keuntungan-keuntungan yang sulit dinyatakan dengan sejumlah uang, namun benar-benar dapat dirasakan, seperti keamanan dan kenyamanan. Dalam penelitian ini untuk penghitungan hanya didapat dari manfaat langsung dan sifatnya terbatas, karena tingkat kesulitan menilainya secara ekonomi.

\section{$\underline{\text { Metode CBA }}$}

Cambell \& Ricard (2003) menyatakan "Social benefit-cost analysis is a process of identifying, measuring and comparing the social benefits and costs of an investment projector program." Social benefit-cost analysis atau analisis biaya sosial.

Pada dasarnya untuk menganalisis efisiensi suatu proyek langkah-langkah yang harus diambil adalah :

- Menentukan semua manfaat dan biaya dari proyek yang akan dilaksanakan

- Menghitung manfaat dan biaya dalam nilai uang

- Menghitung masing-masing manfaat dan biaya dalam nilai uang sekarang

Cambell \& Ricard B. (2003) menyatakan ada 3 teknik analisis yang biasa digunakan dalam Cost Benefit Analysis (CBA) yakni Net Present Value (NPV), Internal Rate of Return (IRR), Benefit-Cost Ratio (BCR), dan Payback Period (PP).

Metode Payback Period (PP).

Metode ini mencoba mengukur seberapa cepat investasi bisa kembali. Karena itu satuan hasilnya bukan persentase. Tetapi satuan waktu (bulan, tahun, dan sebagainya). Karena model ini mengukur seberapa cepat suatu investasi bisa kembali, maka dasar yang dipergunakan adalah aliran kas (cash flow).

\section{Metode NPV (Nilai Bersih Sekarang).}

Metode ini menghitung selisih antara nilai sekarang inventasi dengan nilai sekarang penerimaan-penerimaan kas bersih di massa yang akan datang.untuk mengitung nilai sekarang tersebut perlu ditentukan terlebih dahulu tingkat bunga yang dianggap relevan. Analisis ini dapat dihitung menggunakan rumussebagai berikut (Mangkoesoebroto, 1994). 


$$
\begin{aligned}
& N P V=\sum_{i=1}^{n} N B_{i}(1+i)^{-n} \\
& \text { atau } \\
& N P V=\sum_{i=1}^{n} \frac{N B_{i}}{(1+i)^{n}} \\
& \text { atau } \\
& N P V=\sum_{i=1}^{n} \overline{B_{i}}-\overline{C_{i}}=\sum_{i=1}^{n} N \overline{B_{i}}
\end{aligned}
$$

Dimana :

$\mathrm{NB}=$ Net Benefit $=$ Benefit - Cost

$\mathrm{C}=$ Biaya Investasi + Biaya Operasi

B = Benefit yang telah di diskon

$\mathrm{C} \quad=$ Cost yang telah di diskon

$\mathrm{i} \quad=$ Tingkat diskonto

$\mathrm{n} \quad=$ Tahun (waktu ekonomis).

\section{Metode NPB (Net Present Benefit)}

Proyek yang efisien adalah proyek yang manfaatnya lebih besar dari pada biaya yang diperlukan. Nilai bersih suatu proyek merupakan seluruh nilai dari manfaat proyek dikurangkan dengan biaya proyek pada tahun yang bersangkutan. Rumus perhitungannya adalah sebagai berikut (Mangkoesoebroto, 1994).

$$
N P B=\sum_{t=0}^{T} \frac{M_{t}-B_{t}}{(1+i)^{t}}
$$

dengan :

$$
\begin{array}{ll}
N P B & : \text { nilai bersih sekarang } \\
i & : \text { tingkat diskonto } \\
T & : \text { umur proyek } \\
t & : \text { tahun }=0,1,2, \ldots, \mathrm{T} \\
M & : \text { manfaat } \\
B & : \text { biaya }
\end{array}
$$

Metode IRR (Internal Rate of Return).

Dengan metode ini tingkat diskonto dicari sehingga menghasilkan nilai sekarang suatu proyek sama dengan nol. Rumus yang digunakan adalah sebagai berikut (Soeharto, 1999).

$$
\sum_{t=0}^{T} \frac{M_{t}-B_{t}}{(1+I R R)^{t}}=0
$$

Proyek yang mempunyai nilai IRR yang tinggi yang mendapat prioritas. Suatu proyek akan dilaksanakan dengan mempertimbangkan tingkat pengembalian (IRR) dan tingkat diskonto (i). Tingkat diskonto merupakan biaya pinjaman modal yang harus diperhitungkan dengan tingkat pengembalian investasi. Investor akan melaksanakan semua proyek yang mempunyai IRR > i dan tidak melaksanakan investasi pada proyek yang harga IRR < i. 
Metode Perbandingan Manfaat dan Biaya (BCR)

Dengan kriteria ini maka proyek yang dilaksanakan adalah proyek yang mempunyai angka perbandingan lebih besar dari satu. Rumus perhitungan disampaikan sebagai berikut (Mangkoesoebroto, 1994).

$$
B C R=\frac{\sum_{t=0}^{T} \frac{M_{t}}{(1+i)^{t}}}{\sum_{t=0}^{T} \frac{B_{t}}{(1+i)^{t}}}
$$

Berdasarkan metode ini, suatu proyek akan dilaksanakan apabila BCR > 1. Metode BCR akan memberikan hasil yang konsisten dengan metode NPD, apabila BCR > 1 berarti pula NPB $>0$.

\section{Analisis SWOT (Strengths, Weaknesses, Oportunities, Threaths)}

Analisis SWOT yang merupakan singkatan dari Strengths, Weaknesses, Oportunities and Threats adalah metode perencanaan strategis yang digunakan untuk mengevaluasi kekuatan, kelemahan, peluang, dan ancaman dalam suatu proyek/tugas. Proses ini melibatkan penentuan tujuan yang spesifik dari spekulasi bisnis atau proyek dengan mengindetifikasi faktor internal dan eksternal yang mendukung dan yang tidak dalam mencapai tujuan tersebut.

Alat yang digunakan untuk memetakan faktor -faktor tersebut adalah matrik SWOT, matrik ini dapat menggambarkan secara jelas bagaimana peluang dan ancaman eksternal yang dihadapi dapat disesuaikan dengan kekuatan dan kelemahan yang dimilikinya.

Menurut Rangkuti (2011), analisis SWOT dalam hal ini diarahkan untuk dapat memberikan arahan bagi pengembangan strategi positioning melalui SWOT Matrix, yang dapat dilihat pada Tabel 1.

1. External Factor Analysis Summary (EFAS): rangkuman keseluruhan faktor eksternal yang mempengaruhi yang terdiri dari opportunities dan threats, yang diberikan bobot skala melalui EFE Matrix.

2. Internal Factor Analysis Summary (IFAS): rangkuman keseluruhan faktor internal yang mempengaruhi yang terdiri dari stregths dan weaknesses, setelah diberikan bobot skala melalui IFE Matrix.

3. Strategic Factor Analysis Summary (SFAS) : merupakan rangkuman baik faktor eksternal maupun internal, kemudian dilakukan cross analysis dan diberikan pembobotan. 
Tabel 1. Matriks SWOT

\begin{tabular}{|c|c|c|}
\hline()$^{\text {IFAS }}$ & STRENGTHS (S) & WEAKNESSES (W) \\
\hline OPPORTUNITIES (O) & $\begin{array}{c}\text { STRATEGI S-O : } \\
\text { strategi menggunakan } \\
\text { kekuatan untuk } \\
\text { memanfaatkan peluang }\end{array}$ & $\begin{array}{l}\text { STRATEGI W-O : } \\
\text { strategi meminimalkan } \\
\text { kelemahan untuk } \\
\text { memanfaatkan peluang }\end{array}$ \\
\hline THREATS (T) & $\begin{array}{c}\text { STRATEGI S-T : } \\
\text { strategi menggunakan } \\
\text { kekuatan untuk mengatasi } \\
\text { ancaman }\end{array}$ & $\begin{array}{c}\text { STRATEGI W-T : } \\
\text { strategi meminimalkan } \\
\text { kelemahan menghindari } \\
\text { ancaman }\end{array}$ \\
\hline
\end{tabular}

\section{METODOLOGI}

Penelitian Evaluasi Pemanfaatan Aset Barang Milik Daerah Stadion Mandala Krida Yogyakarta dilakukan dengan metodologi dan pendekatan yang dipergunakan dalam Kajian Pemanfaatan Barang Milik Daerah (BMD) memperhatikan kesesuaian terhadap kondisi nyata di lapangan berdasarkan survey dan diinput dari data sekunder. Pendekatan masalah terkait dengan metodologi adalah dengan pendekatan Cost and Benefit Analysis (CBA) dan SWOT (Strengths, Weaknesses, Oportunities \& Threats) untuk mengetahui strategi pemanfaatannya.

\section{PEMBAHASAN}

Dalam analisis ini terdapat pembahasan mengenai analisa perbandingan terhadap pendapatan dan biaya, yang kemudian langkah berikutnya adalah mencari Net Present Value (NPV) dan Internal Rate Return (IRR). Untuk mencari NPV atau IRR tersebut maka diperlukan pengukuran mengenai tingkat resiko yang sesuai dengan karakteristik dari operasional aset. Aset yang dilakukan analisis cost and benefit dalam penelitian ini adalah Stadion Mandala Krida Yogyakarta. Berikut adalah detail perhitungan dari tingkat resiko dan analisis cost and benefit dari masing - masing aset.

\section{Tingkat Diskonto}

Tingkat diskonto ditentukan dengan menggunakan metode Cost of Equity, dengan menggunakan rumus sebagai berikut (Hanafi \& Halim, 2016).

$$
\begin{aligned}
\mathrm{Ke}=\mathrm{Rf} & +(\beta \times(\text { RPm-Rbds })) \\
\text { Dimana } & : \\
\mathrm{ke} & =\text { Biaya Modal } \\
\mathrm{Rf} & =\text { Tingkat pengembalian bebas risiko } \\
\beta & =\text { Beta } \\
\mathrm{Rpm} & =\text { Risk Premium Market } \\
\mathrm{Rbds} & =\text { Risk based default spread }
\end{aligned}
$$

Pada Tabel 2 disampaikan asumsi yang digunakan dalam perhitungan tingkat diskonto adalah sebagai berikut. 
(e)ISSN 2615-1847 (p)ISSN 2615-1839

Jurnal Manajemen Aset Infrastruktur \& Fasilitas - Vol. 4, No. 1, Januari 2020

Tabel 2. Tingkat Diskonto

\begin{tabular}{|c|c|c|c|}
\hline \multicolumn{4}{|c|}{ Perhitungan Discount Rate } \\
\hline Keterangan & & Angka & Sumber \\
\hline Cost of Debt & $=$ & $10,07 \%$ & Bank Indonesia \\
\hline Risk Free & $=$ & $8,78 \%$ & www.investing.com per 18 juli 2018 Bond Tenor $30 \mathrm{~T}$ \\
\hline Beta & $=$ & 1,06 & Aswath Damoradan (2018) \\
\hline Risk Premium Market & $=$ & $7,62 \%$ & Aswath Damoradan (2018) \\
\hline Risk Based Default Spread & $=$ & $2,26 \%$ & Aswath Damoradan (2018) \\
\hline Equity Ratio & $=$ & $100 \%$ & \\
\hline \multirow[t]{2}{*}{ Cost of equity } & $=$ & \multicolumn{2}{|c|}{ Risk Free + (Beta $\times$ Risk Premium Market) } \\
\hline & $=$ & \multicolumn{2}{|c|}{$14,48 \%$} \\
\hline \multirow[t]{2}{*}{ Discount Rate } & $=$ & \multicolumn{2}{|c|}{ Risk Free + (Beta $x$ Risk Premium Market) } \\
\hline & $=$ & \multicolumn{2}{|c|}{$14,48 \%$} \\
\hline
\end{tabular}

Dengan mempertimbangkan faktor-faktor di atas dan kekuatan / kelebihan serta risiko yang dihadapi, maka kami diambil tingkat diskonto yang digunakan adalah sebesar $14.48 \%$.

Perhitungan Analisis Keuangan dari Stadion Mandala Krida, disampaikan dan dapat dilihat pada Tabel 3 sebagai berikut.

Tabel 3. Analisis Cost and Benefit Stadion Mandala Krida

\begin{tabular}{|c|c|c|c|c|}
\hline Tahun & 2015 & 2016 & 2017 & 2018 \\
\hline Pendapatan Kotor & 188.185 .000 & 203.700 .000 & 267.800 .000 & 320.974 .892 \\
\hline \multicolumn{5}{|l|}{ Biaya Operasional } \\
\hline Telepon & 1.825 .591 & 1.921 .675 & 2.022 .816 & 2.129 .280 \\
\hline Listrik & 76.471 .995 & 80.496 .837 & 84.733 .512 & 89.193.171 \\
\hline Kebersihan & 312.802 .153 & 329.265 .425 & 346.595 .184 & 364.837 .036 \\
\hline Keamanan & 123.250 .306 & 129.737.165 & 136.565 .436 & 143.753.091 \\
\hline Pemeliharaan Bangunan & 75.000 .000 & 84.000 .000 & 7.149.382 & 45.520 .400 \\
\hline Instalasi Air Bersih & 845.181 & 889.664 & 936.489 & 985.778 \\
\hline Instalasi Listrik & 676.145 & 711.732 & 749.191 & 788.622 \\
\hline Instalasi Air Limbah & 836.729 & 880.768 & 927.124 & 975.920 \\
\hline Instalasi Telepon & 676.145 & 711.732 & 749.191 & 788.622 \\
\hline Instalasi Jaringan Komputer & 836.729 & 880.768 & 927.124 & 975.920 \\
\hline Pemeliharaan Alat Berat & 1.690 .362 & 1.779 .329 & 1.872 .978 & 1.971 .556 \\
\hline Jumlah & 514.350 .046 & 541.421 .101 & 583.228 .427 & 651.919.395 \\
\hline Net Income & -326.165 .046 & -337.721 .101 & -315.428 .427 & -330.944 .503 \\
\hline Growth & & $3,5 \%$ & $-6,6 \%$ & $4,9 \%$ \\
\hline Terminal Value & & & & -3.316 .668 .851 \\
\hline Cash Flow & & & & -3.647 .613 .354 \\
\hline Discount Factor & & & & 0,8735 \\
\hline PV & & & & -3.186 .324 .931 \\
\hline NPV & & & & -3.186 .324 .931 \\
\hline
\end{tabular}

Dari data Tabel 3 diatas dapat diketahui bahwa perbandingan antara pendapatan dan biaya adalah lebih besar biaya sehingga menimbulkan net income atau pendapatan yang negatif atau dengan kata lain mengalami kerugian dari sisi keuangan. Karena net income yang dihasilkan adalah negatif, maka Net Present Value (NPV) juga akan negatif, sehingga tidak diperlukan 
pembuktian lagi melalui IRR. Dengan begitu, dapat disimpulkan bahwa aset Stadion Mandala Krida tidak menguntungkan untuk penggunaan saat ini jika dilihat dari segi keuangan.

Kemudian, Cost and Benefit Analysis, dilanjutkan dengan Analisis Pemanfaatan dan Pembobotan dengan menggunakan SWOT. Analisis ini disampaikan dan dapat dilihat pada Tabel 4. dan Tabel 5.

Tabel. 4. Analisis Pemanfaatan SWOT

\begin{tabular}{|c|c|}
\hline \multicolumn{2}{|c|}{ Analisa SWOT faktor internal strategi } \\
\hline Strength & Weakness \\
\hline Kondisi gedung baru dan megah & $\begin{array}{lll}\begin{array}{l}\text { Belum selesainya } \\
\text { menyeluruh }\end{array} & \text { renovasi secara } \\
\end{array}$ \\
\hline $\begin{array}{l}\text { Memiliki kelebihan fasilitas lintasan atletik } \\
\text { dengan } 2 \text { warna }\end{array}$ & Fasilitas kantong parkir terbatas dan jauh \\
\hline Memiliki fasilitas olahraga yang lengkap & Lahan pengembangan terbatas \\
\hline $\begin{array}{l}\text { Daya tampung diatas } 30.000 \text { penonton } \\
\text { termasuk dalam kategori tipe } \mathrm{A}\end{array}$ & $\begin{array}{l}\text { Belum tersedianya fasilitas kuliner } \\
\text { mengakibatkan pedagang yang sembarangan } \\
\text { berjualan }\end{array}$ \\
\hline Ikon olah raga di Yogyakarta & Belum berfungsinya semua toilet di stadion \\
\hline $\begin{array}{l}\text { Adanya aktivitas latihan rutin bola voli pasir, } \\
\text { panjat tebing, sepatu roda,bola basket dan } \\
\text { balap motor }\end{array}$ & $\begin{array}{l}\text { Fasilitas lampu penerangan masih sangat } \\
\text { minim }\end{array}$ \\
\hline $\begin{array}{l}\text { Adanya pemanfaatan lain seperti event- } \\
\text { event temporer (musik/konser, kuliner, } \\
\text { pameran/bazar dan lain-lain) }\end{array}$ & Pedagang kaki lima yang sulit diatur \\
\hline \multirow{5}{*}{$\begin{array}{l}\text { Adanya perencanaan kegiatan baru setelah } \\
\text { renovasi selesai seperti latihan rutin atletik, } \\
\text { latihan bola basket dimalam hari dan } \\
\text { pertandingan bola baik skala lokal maupun } \\
\text { nasional }\end{array}$} & $\begin{array}{l}\text { Jalur aksesibilitas disekitar area sempit dan } \\
\text { padat }\end{array}$ \\
\hline & $\begin{array}{l}\text { Informasi hanya didapat melalui website } \\
\text { BPO Disdikpora DIY }\end{array}$ \\
\hline & $\begin{array}{l}\text { Pembatasan aktivitas segmen pasar pelajar } \\
\text { untuk menghindari tindakan kriminalitas }\end{array}$ \\
\hline & $\begin{array}{l}\text { Belum adanya perencanaa perluasan } \\
\text { kerjasama }\end{array}$ \\
\hline & Wewenang sebatas pengguna dan pemelihara \\
\hline $\begin{array}{l}\text { Menjadi satu-satunya gedung termegah } \\
\text { untuk kategori stadion olahraga di } \\
\text { Yogyakarta }\end{array}$ & Pesaing fasilitas olah raga baru milik swasta \\
\hline $\begin{array}{l}\text { Sebagai pusat sarana } \\
\text { edukasi,rekreasi,hiburan, public space dan } \\
\text { olah raga }\end{array}$ & $\begin{array}{l}\text { Hilangnya target pasar utama dan pasar } \\
\text { potensial }\end{array}$ \\
\hline $\begin{array}{l}\text { Menjadi lokasi penyelenggaraan laga-laga } \\
\text { berskala internasional }\end{array}$ & $\begin{array}{l}\text { Ketidakcocokan kerjasama antar instansi } \\
\text { terkait }\end{array}$ \\
\hline Peningkatan jejaring kerjasama/ BUMD & $\begin{array}{l}\text { Tidak adanya ketertarikan investor dalam } \\
\text { pengembangan dan pengelolaan aset }\end{array}$ \\
\hline $\begin{array}{l}\text { Peningkatan kesejateraan dan partisipasi } \\
\text { masyarakat }\end{array}$ & $\begin{array}{l}\text { Peran serta masyarakat dalam pemeliharaan } \\
\text { kawasan rendah }\end{array}$ \\
\hline
\end{tabular}

\section{Analisis Pembobotan SWOT Stadion Mandala Krida}

Setelah perhitungan aspek finansial bisa diselesaikan, analisis sampai pada Aspek Penentuan Strategi Penanganan Stadion Mandala Krida. Penentuan Langkah Strategi Pelaksanaan dilakukan dengan menggunakan Teknik Analisis SWOT. Analisis Pembobotan Atribut SWOT disampaikan pada Tabel 5 sebagai berikut. 
Tabel 5. Nilai Persepsi dan Ekspetasi SWOT Stadion Mandala Krida

\begin{tabular}{|c|l|c|c|}
\hline No & \multicolumn{1}{|c|}{ Atribut } & $\begin{array}{c}\text { X } \\
\text { persepsi }\end{array}$ & $\begin{array}{c}\text { Y } \\
\text { ekspektasi }\end{array}$ \\
\hline 1 & Kondisi fisik bangunan & 4,5 & 5 \\
\hline 2 & Karakteristik lingkungan & 4 & 5 \\
\hline 3 & Sistem pengelolaan & 4,2 & 4,5 \\
\hline 4 & Manajemen keuangan & 4,3 & 4,8 \\
\hline 5 & Sistem pemasaran & 4 & 5 \\
\hline 6 & Nilai pemanfaatan & 4,5 & 5 \\
\hline 7 & Sistem kerjasama & 3 & 5 \\
\hline
\end{tabular}

Hasil Penilaian Atribut Stadion Mandala Krida dalam aspek Persepsi dan Ekspetasi bisa dipetakan pada Segi Empat Kwadran Pemetaan Persepsi dan Ekspetasi. Pemetaan tersebut disampaikan pada Gambar 1 sebagai berikut.

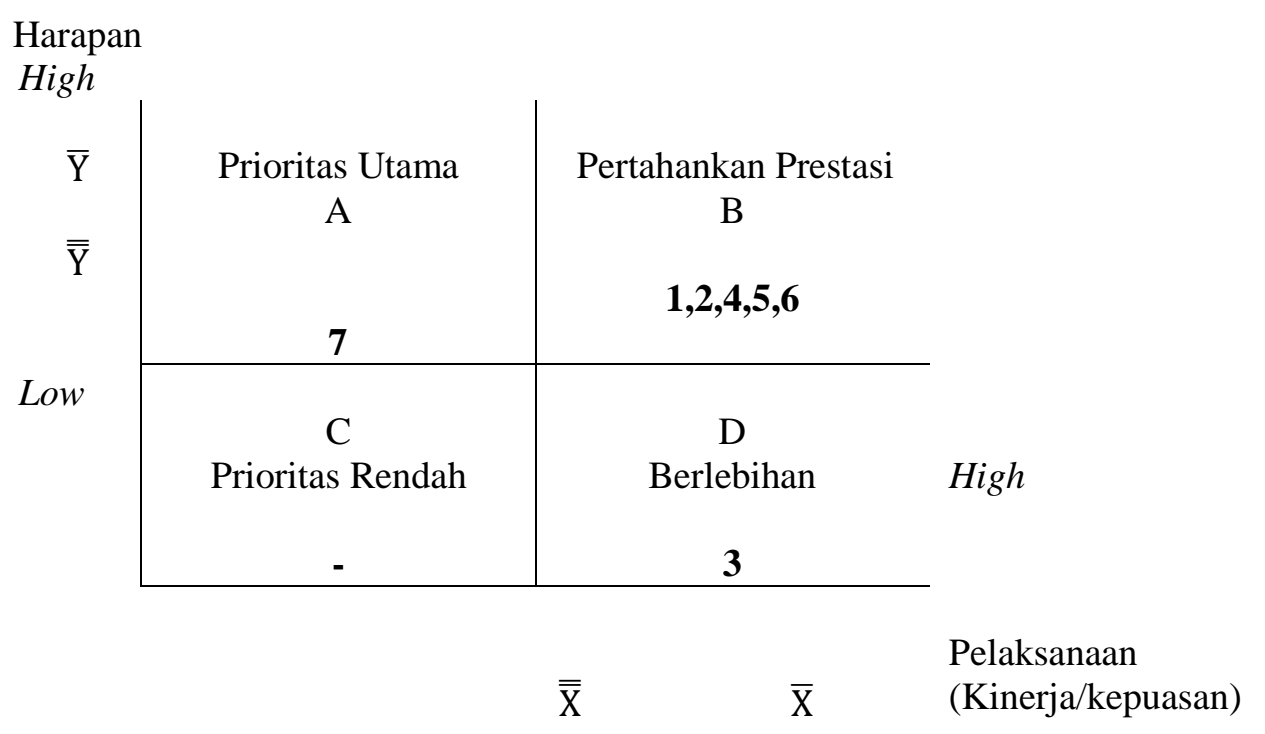

Gambar 1. Segi Empat Pemetaan Kwadran Persepsi dan Ekspetasi

Pemetaan Persepsi dan Ekspetasi disusun lebih rinci pada Gambar 2 Atribut pada keempat Kwadran. Perincian letak bisa disampaikan sebagai berikut.

- Atribut Sistem Kerjasama

Atribut ini berkoordinat Persepsi 3, Ekspetasi 5. Atribut ini berada pada Kwadran A, berarti bersifat Prioritas Utama.

- Atribut Sistem Pengelolaan

Atribut ini berkoordinat Persepsi 4,2, Ekspetasi 4,5. Atribut ini berada pada Kawasan Kwadran Berlebihan.

- Atribut Kondisi Fisik Bangunan, Karakteristik Lingkungan, Manajemen Keuangan, Sistem Pemasaran, Nilai Pemanfaatan.

Kelima atribut ini berada pada Kwadran Pertahankan Prestasi. Diantara kelima atribut diatas, atribut Karakteristik Lingkungan dan Sistem Pemasaran perlu mendapat dikembangkan lebih dibanding tiga atribut yang lain. 


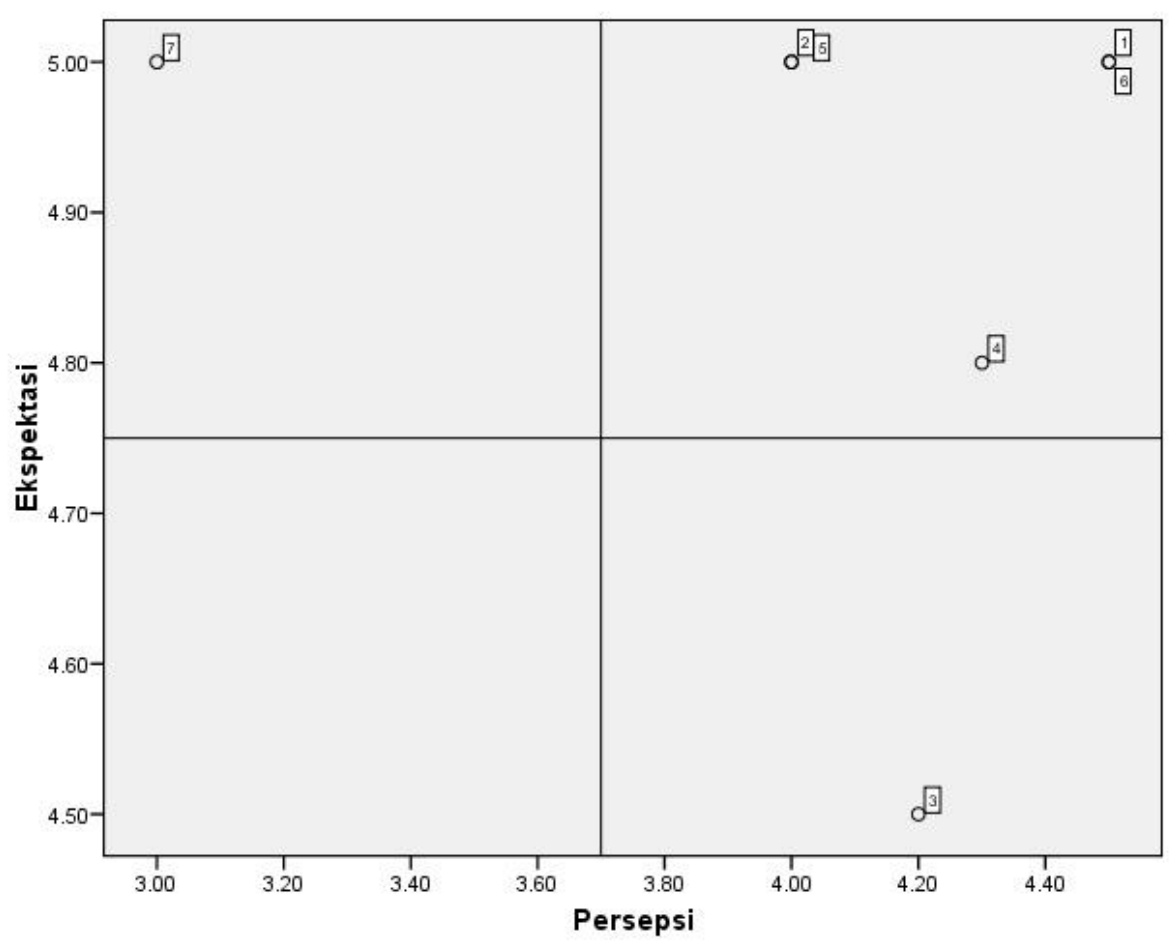

Gambar 2. Analisis Kuadran Kartesius Stadion Mandala Krida

Gambar 2 diatas menunjukkan perlunya peningkatan kinerja untuk atribut Sistem Kerjasama. Atribut sistem pengelolaan masuk dalam Kuadran D dimaksudkan kinerja yang berlebihan namun belum diperlukan oleh pasar. Sedangkan untuk atribut yang lain diperoleh kinerja berprestasi maka diperlukan penguatan dan pengembangan lanjutan. Sehingga dari pembobotan tersebut didapatkan matriks strategi, yang disampaikan dibawah ini pada Tabel 6 .

Tabel 6. Matriks Analisis SWOT

\begin{tabular}{|c|c|c|}
\hline IFAS & STRENGTHS (S) & WEAKNESSES (W) \\
\hline $\begin{array}{l}\text { OPPORTUNITIES } \\
(\mathrm{O})\end{array}$ & $\begin{array}{l}\text { STRATEGI S-O : } \\
\text { 1. Pengembangan wisata } \\
\text { minat khusus "sport } \\
\text { tourism" } \\
\text { 2. Penyelenggaran Big Sport } \\
\text { Even dan Sporting Tourism } \\
\text { of the practicioners } \\
\text { 3. Pengembangan fasilitas } \\
\text { untuk MICE bertema "sport } \\
\text { tourism" } \\
\text { 4. Perluasan jejaring } \\
\text { kerjasama dengan pihak } \\
\text { luar negeri } \\
\text { 5. Menjalin perluasan } \\
\text { kerjasama dengan investor } \\
\text { swasta, dan institusi dalam } \\
\text { dan luar negeri }\end{array}$ & $\begin{array}{ll}\text { STRATEGI W-O : } \\
\text { 1. Peningkatan keterlibatan } \\
\text { masyarakat dalam } \\
\text { pengelolaan }\end{array}$ \\
\hline
\end{tabular}




\begin{tabular}{|c|c|c|}
\hline \multirow{6}{*}{ THREATS (T) } & \multirow{6}{*}{ 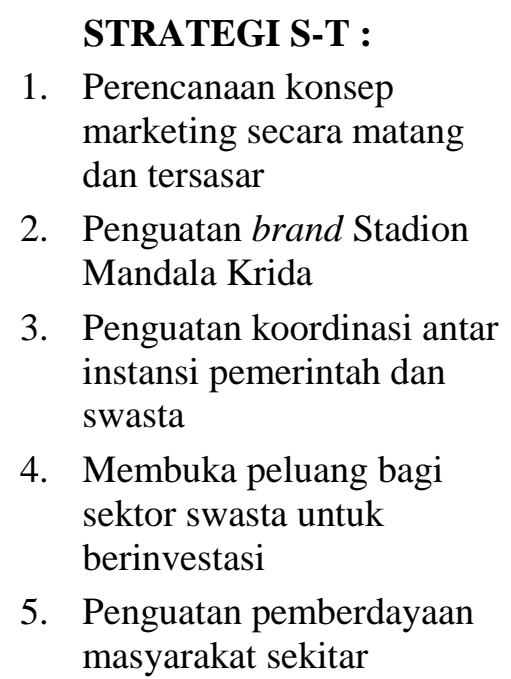 } & $\begin{array}{l}\text { STRATEGI W-T : } \\
\text { 1. } \\
\text { Peningkatan pengawasan } \\
\text { terhadap pemeliharaan } \\
\text { Stadion Mandala Krida }\end{array}$ \\
\hline & & $\begin{array}{l}\text { 2. Peningkatan skill SDM } \\
\text { dalam hal pengembangan }\end{array}$ \\
\hline & & $\begin{array}{l}\text { pemasaran } \\
\text { 3. Menjaga komunikasi yang } \\
\text { efektif dan tetap kondusif }\end{array}$ \\
\hline & & antar instansi terkait \\
\hline & & $\begin{array}{l}\text { 4. Melakukan sosialisasi \& } \\
\text { pelatihan pelayanan untuk }\end{array}$ \\
\hline & & masyarakat \\
\hline
\end{tabular}

Aset Stadion Mandala Krida bahwa, secara keuangan memang terdapat kerugian. Akan tetapi bahwa Stadion Mandala Krida merupakan fasilitas publik yang terdapat unsur pembinaan olahraga untuk bibit-bibit muda. Oleh karena itu, bentuk pemanfaatan sekarang yang dikelola oleh Balan Pemuda Olahraga sebaiknya dipertahankan dengan tambahan inovasi tertentu.

\section{KESIMPULAN}

Pemanfaatan Stadion Mandala Krida sudah sesuai dengan Peraturan Tata Kota, dan peruntukan yang ideal yaitu sebagai sarana olahraga. Guna peningkatan manfaat dan meningkatkan profesionalitas dalam pengelolaan, peneliti merekomendasikan pengelolaan dilakukan melalui Badan Layanan Umum. Pengelolaan melalui BLU lebih fleksibel di dalam pengelolaan, efisiensi, dan optimalisasi produktifitas tetapi juga tetap mengedepankan pelayanan kepada masyarakat.

\section{DAFTAR PUSTAKA}

Campbell, H. \& Ricard B. (2003). Benefit-Cost Analysis Financial and Economics Apraisal Using Spreadsheet. Cambrige Press. New York.

David, F.R. (2011). Manajemen Strategis: Konsep-Konsep. Edisi Duabelas. Salemba Empat. Jakarta.

Hanafi, M.M. \& Abdul Halim. (2016). Analisis Laporan Keuangan. Edisi Kelima. UPP STIM YKPN. Yogyakarta.

Kadariah (1999). Evaluasi Proyek Analisis Ekonomi. Lembaga Penelitian Fakultas Ekonomi UI. Jakarta.

Lawrence, Sarah \& Daniel P. Mears (2004). Benefit-Cost Analysis of Supermax Prisons: Critical Steps and Considerations. The Urban Institute. Washington D.C.

Mangkoesoebroto, G. (1994). Ekonomi Publik. BPFE - Badan Penerbit Fakultas Ekonomi. Universitas Gajah Mada. Yogyakarta.

Rangkuti, F. (2011). SWOT Balance Scorecard. PT Gramedia Pustaka. Jakarta.

PemProv DIY (2017). Rencana Pembangunan Jangka Menengah Daerah (RPJMD) Daerah Istimewa Yogyakarta Tahun 2017-2022. Pemerintah Provinsi Daerah Istimewa Yogyakarta.

Soeharto, I. (1999). Manajemen Proyek: dari Proyek Konseptual sampai Operasional. Jilid I \& II. Erlangga. Jakarta.

Suprayitno, H. \& Soemitro, R.A.A. (2018). "Preliminary Reflexion on Basic Principle of Infrastructure Asset Management”. Jurnal Manajemen Aset Infrastruktur \& Fasilitas, Vol. 2, No. 1, Maret 2018, Hal. : 1-10. 